\title{
The Mortality Rate and Affecting Factors in Patients with Community-Based Pneumonia Requiring Hospitalization
}

\author{
Mutlu KULUÖZTÜRK ${ }^{1}$, Gülden ESER KARLIDAĞ ${ }^{2}$, \\ Gökçen AĞAOĞLU ÇELiK ${ }^{1}$, Figen DEVECI ${ }^{1}$
}

\begin{abstract}
Objective: The aim of this study is to determine the mortality rate and affecting factors in patients with community-acquired pneumonia (CAP) requiring hospitalization.

Material and Methods: 150 cases with CAP were evaluated retrospectively. Age, gender, hospital mortality, presence of concomitant disease, smoking history, history of intensive care unit and invasive mechanical ventilation, hospitalization time, arterial oxygen saturation $\left(\mathrm{SaO}_{2}\right)$, CURB-65 score, sputum culture results, values of pulse, arterial blood pressure, fever, respiratory rate, confusion status, hemogram, urea, creatinine, $\mathrm{C}$-reactive protein $(\mathrm{CRP})$ and procalcitonin (PCT) values were recorded from our hospital's database system.

Results: The hospital mortality rate was $12.7 \%(\mathrm{n}=19)$. The mean age, CURB65 scores, fewer, respiratory rate, neutrophil counts, urea, CRP levels and PCT positivity were statistically increased and $\mathrm{SaO}_{2}$ levels, systolic TA, diastolic TA, lymphocytes and platelet counts were statistically decreased in CAP patients with died in-hospital. Logistic regression showed that need for invasive mechanical ventilation, confusion status and PCT positivity were significantly associated with in-hospital mortality.

Conclusion: Advanced age, high neutrophil ratio, high CURB-65 score and low systolic TA values are related factors with hospital mortality in patients with CAP requiring hospitalization. In addition, invasive mechanical ventilation, confusion status and PCT positivity are independent risk factors for hospital mortality in CAP patients.
\end{abstract}

Key Words: Community-acquired pneumonia, Mortality, CURB-65

\section{Hastaneye Yatış Gerektiren Toplum Kökenli Pnömoni Olgularında Mortalite Oranı ve Etkileyen Faktörler}

Öz

Amaç: Çalışmamızda hastaneye yatış gerektiren Toplumda Gelişen Pnömoni (TGP) olgularında mortalite oranının ve mortaliteyi etkileyen faktörlerin belirlenmesi amaçlanmıştır.

Gereç ve Yöntem: 150 TGP'li olgu retrospektif olarak değerlendirilmiştir. Yaş, cinsiyet, hastane mortalitesi, eşlik eden hastalık varlığı, sigara öyküsü, yoğun bakım ve invaziv mekanik ventilasyon öyküsü, hastane yatış süresi, arteryel oksijen satürasyonu $\left(\mathrm{SaO}_{2}\right)$, CURB-65 skoru, balgam kültür sonuçları, nabız, arteryel kan basınc1, ateş, solunum sayısı, konfüzyon durumu, hemogram, üre, kreatinin, C-reaktif protein (CRP) ve prokalsitonin (PCT) değerleri kaydedilmiştir.

Bulgular: Hastane mortalite oranı \% $12.7(\mathrm{n}=19)$ olarak saptand1. Hastanede ölen TGP olgularında ortalama yaş, CURB-65 skoru, ateş, solunum sayısı, nötrofil sayısı, üre, CRP düzeyleri ve PCT pozitifliği istatistiksel olarak artmış ve $\mathrm{SaO}_{2}$, sistolik TA, diastolic TA, lenfosit ve trombosit sayısı istatistiksel olarak azalmıştı. Lojistik regresyon analizine göre invaziv mekanik ventilasyon gereksinimi, konfüzyon varlığı ve PCT pozitifliği hastane mortalitesi ile anlamlı düzeeyde ilişkili olarak bulundu.

Sonuç: İleri yaş, yüksek nötrofil oranı, yüksek CURB-65 skoru ve düşük sistolik TA değerleri

${ }^{1}$ Firat University Faculty of Medicine, Department of Chest Diseases Elazig, Turkey

${ }^{2}$ Ministry of Health Elaziğ Fethi Sekin City Hospital, Infectious Diseases and Clinical Microbiology, Elazıg, Turkey

Corresponding author: Dr. Figen Deveci, Firat University Faculty of Medicine, Department of Chest Diseases, 23119

Elazig, Turkey, e-mail: fgndeveci@yahoo.com, ORCID ID: 0000-0001-6670-3620.

Geliş Tarihi: 2 Şubat $2021 \quad$ Kabul Tarihi: 22 Şubat 2021

DOI: 10.17932/IAU.TFK.2018.008/tfk_v04i1004 
hastaneye yatış gerektiren TGP olgularında mortalite ile ilişkili faktörlerdir. Ek olarak invaziv mekanik ventilasyon, konfüzyon varlığı ve PCT pozitifliği TGP olgularında hastane mortalitesi için bağımsız risk faktörleridir.

Anahtar kelimeler; Toplumda gelişen pnömoni, Mortalite, CURB-65

\section{Introduction}

Community-acquired pneumonia (CAP) is a common health problem which cause of morbidity and mortality (1). Incidence and mortality of CAP are depending on age and comorbidity $(2,3)$. Hospitalized patients with CAP have mortality rate is approximately $13 \%$ (4). The most important early prognostic parameters of CAP are acute respiratory insufficiency and acute extra pulmonary organ dysfunction due to sepsis or comorbidities (57).

Lower respiratory tract infections rank 5 th with $4.2 \%$ among causes of death in our country (8). All $1.9 \%$ of hospitalizations were constituted by pneumonia patients according to Ministry of Health 2004 health records in our country (9). Mortality of CAP varies between $1 \%$ $60 \%$ in our country and the mortality rate in hospitalized patients with CAP is significantly higher (10.3-60\%) depending on the severity of the disease (10).

The aim of our study is to determine the mortality rate CAP patients and to find out the mortality risk factors in hospitalized patients with CAP.

\section{Methods}

\section{Study Design and Patients}

This retrospective study was performed at Firat University Chest Disease Department. Our hospital's electronic patient database was searched between January 1, 2018 and May 20, 2019 using the ICD-10 search code "J18.9" for the patients with CAP directly hospitalized in our clinic and 150 patients were included in the study retrospectively. Ethical approval was obtained by the institutional review board (07.02.2019-81527325).

Demographic characteristics, hospital mortality, concomitant disease, smoking history, history of intensive care and invasive mechanical ventilation, hospitalization time, $\mathrm{SaO}_{2}$, CURB-65 score (confusion, urea nitrogen, respiratory rate, blood pressure, age $\geq 65$ years), results of sputum culture, pulse, blood pressure, fewer, respiratory rate, confusion, hemogram, urea, creatinine, CRP and PCT values were recruited from our hospital electronic database. Laboratory parameters were obtained at admission and before treatment. Peripheral blood samples were taken into calcium-EDTA tubes, blood counts and differences were analyzed using an auto analyzer.

Patients with a diagnosis of hospital-acquired pneumonia without radiological evidence, an immunocompromised condition (solid organ or bone marrow transplant or immunosuppressive therapy), asthma, active tuberculosis, or other lung disease were excluded in the study.

\section{Statistical analysis}

IBM Statistical Product and Service Solutions version 21.0 (IBM SPSS Statistics 21 program, Armonk, NY, USA) software was used to evaluate the data. Variables were expressed using mean \pm standard deviation and percentage. Pairwise group variables were statistically compared using Mann-Whitney tests was used because of our data not showing normal distribution. Variables with categorical data were statistically compared using chisquare tests. Calculation of odds ratios (ORs) and $95 \%$ CI values for mortality rate, with relation to potential risk factors, was performed with binary logistic regression models. Results are expressed as means \pm standard deviations. For the significance level of the tests, $p<0.05$ were accepted.

\section{Results}

Mean age of the 150 patients was $67.07 \pm$ 
16.29 years (range, 21-97), being 40 males and 110 females. The hospital mortality rate was $12.7 \%(\mathrm{n}=19)$. The baseline characteristics of patients are presented in Table 1 . The mean age, CURB65 scores, fewer, respiratory rate, neutrophil counts, urea, PCT positivity and CRP levels were statistically increased and $\mathrm{SaO}_{2}$ levels, systolic TA, diastolic TA, lymphocytes and platelet counts were statistically decreased in CAP patients with died in-hospital (Table 1). Comorbidities, smoking history, invasive mechanical ventilation (IMV), culture positivity and confusion status in patients with CAP are shown in table 2. The use of IMV and confusion status were statistically higher in non-survivor CAP patients compared with survivor CAP patients $\left(X^{2}: 43.395, p=0.000\right.$; $X^{2}: 68.572, p=0.000$, respectively).

The results of binary logistic analyses are shown in Table 3. Univariate logistic regression showed that need for invasive mechanical ventilation, confusion status and procalcitonin positivity were significantly associated with inhospital mortality.

Table 1. Baseline Characteristics and Clinical Parameters in Patients with CAP.

\begin{tabular}{lcccc}
\hline Variables & $\begin{array}{c}\text { Total } \\
(\mathbf{n}=\mathbf{1 5 0})\end{array}$ & $\begin{array}{c}\text { Survivors } \\
(\mathbf{n}=\mathbf{1 3 1})\end{array}$ & $\begin{array}{c}\text { Non-survivors } \\
(\mathbf{n}=\mathbf{1 9})\end{array}$ & $\boldsymbol{p}$ value \\
\hline Age $($ years) & $67.07 \pm 16.29$ & $65.07 \pm 16.29$ & $76 \pm 14.7$ & 0.004 \\
Male, $\mathrm{n}(\%)$ & $103(68.7)$ & $90(68.7)$ & $13(68.4)$ & $\mathrm{NS}$ \\
Length of hospital stay (days) & $8.72 \pm 4.89$ & $8.53 \pm 4.74$ & $10 \pm 5.84$ & $\mathrm{NS}$ \\
SaO $(\%)$ & $88.22 \pm 7.41$ & $89.11 \pm 6.99$ & $82.1 \pm 7.48$ & 0.000 \\
CURB65 & $1.19 \pm 1.12$ & $1.02 \pm 1$ & $2.36 \pm 1.21$ & 0.000 \\
Pulse & $91.3 \pm 14.8$ & $90.68 \pm 14.8$ & $95.52 \pm 14.17$ & $\mathrm{NS}$ \\
Systolic TA $(\mathrm{mmHg})$ & $112.6 \pm 16.2$ & $113.89 \pm 15.85$ & $103.68 \pm 16.05$ & 0.022 \\
Diastolic TA $(\mathrm{mmHg})$ & $65.73 \pm 9.83$ & $66.33 \pm 10.1$ & $61.57 \pm 6.88$ & 0.042 \\
Fever $\left({ }^{\circ} \mathrm{C}\right)$ & $37.4 \pm 0.85$ & $37.3 \pm 40.85$ & $37.8 \pm 10.81$ & 0.023 \\
Respiratory rate & $14.41 \pm 2.26$ & $14.2 \pm 12.06$ & $15.7 \pm 83.06$ & 0.014 \\
Hb $(\mathrm{g} / \mathrm{dL})$ & $12.88 \pm 1.99$ & $12.9 \pm 71.97$ & $12.2 \pm 32.02$ & $\mathrm{NS}$ \\
Hct $(\%)$ & $40.5 \pm 6.19$ & $40.7 \pm 56.13$ & $38.8 \pm 6.49$ & $\mathrm{NS}$ \\
Leucocyte $\left(10^{3} / \mu \mathrm{L}\right)$ & $11.61 \pm 8.91$ & $11.69 \pm 9.37$ & $11.02 \pm 4.77$ & $\mathrm{NS}$ \\
Lymphocyte $\left(10^{3} / \mu \mathrm{L}\right)$ & $15.9 \pm 11.17$ & $16.65 \pm 11.40$ & $10.76 \pm 7.94$ & 0.014 \\
Neutrophil $\left(10^{3} / \mu \mathrm{L}\right)$ & $74 \pm 13.58$ & $73.09 \pm 13.63$ & $80.22 \pm 11.73$ & 0.018 \\
Platelet $\left(10^{3} / \mu \mathrm{L}\right)$ & $284.9 \pm 131.9$ & $293.58 \pm 134.27$ & $225.1 \pm 97.59$ & 0.015 \\
Urea $(\mathrm{mg} / \mathrm{dL})$ & $51.52 \pm 35.11$ & $50.08 \pm 36.4$ & $61.67 \pm 22.78$ & 0.002 \\
Creatinine $(\mathrm{mg} / \mathrm{dL})$ & $1.04 \pm 0.72$ & $1.03 \pm 0.75$ & $1.07 \pm 0.51$ & $\mathrm{NS}$ \\
CRP $(\mathrm{mg} / \mathrm{dL})$ & $106.29 \pm 63.3$ & $100.3 \pm 68.91$ & $147.57 \pm 58.33$ & 0.005 \\
Procalcitonin positivity, $\mathrm{n}(\%)$ & $46(30.7)$ & $30(22.9)$ & $16(84.2)$ & 0.000 \\
\hline
\end{tabular}


Table 2. Comorbidities, Smoking History, Invasive Mechanical ventilation (IMV), Culture Positivity and Confusion status in patients with CAP.

\begin{tabular}{|c|c|c|c|c|}
\hline Variables & $\begin{array}{c}\text { Total } \\
(n=150)\end{array}$ & $\begin{array}{c}\text { Survivors } \\
(\mathrm{n}=131)\end{array}$ & $\begin{array}{c}\text { Nonsurvivors } \\
(n=19)\end{array}$ & $p$ value \\
\hline Comorbidities & $110(73.3)$ & $94(71.8)$ & $16(84.2)$ & NS \\
\hline Diabetes, $\mathrm{n}(\%)$ & $17(11.3)$ & $15(88.2)$ & $2(11.8)$ & NS \\
\hline Obstructive Lung Disease, n (\%) & $45(30)$ & $39(86.7)$ & $6(13.3)$ & NS \\
\hline Hypertension, $\mathrm{n}(\%)$ & $12(8)$ & $12(100)$ & $0(0)$ & NS \\
\hline Chronic heart disease, $\mathrm{n}(\%)$ & $7(4.7)$ & $5(71.4)$ & $2(28.6)$ & NS \\
\hline Other, $\mathrm{n}(\%)$ & $29(19.3)$ & $23(79.3)$ & $6(20.7)$ & NS \\
\hline \multicolumn{5}{|l|}{ Smoking History } \\
\hline Current smoker, n (\%) & $77(51.3)$ & $64(48.9)$ & $13(68.4)$ & NS \\
\hline Ex-smoker, n (\%) & $16(10.7)$ & $15(11.5)$ & $1(5.3)$ & NS \\
\hline Newer-smoker, n (\%) & $57(38)$ & $52(39.7)$ & $5(26.3)$ & NS \\
\hline IMV, n (\%) & $18(12)$ & $7(38.9)$ & $11(61.1)$ & 0.000 \\
\hline Culture Positivity, n (\%) & $62(41.3)$ & $53(40.5)$ & $9(47.4)$ & NS \\
\hline Confusion, $\mathrm{n}(\%)$ & $20(13.3)$ & $6(30)$ & $14(70)$ & 0.000 \\
\hline
\end{tabular}

Table 3. Risk Factors Associated with in-Hospital Mortality in Patients with CAP.

\begin{tabular}{lcc}
\hline Variables & $\begin{array}{c}\text { Univariate Regression } \\
\text { OR (95\% CI) }\end{array}$ & $\boldsymbol{p}$ value \\
\hline Comorbidities & $19.686(0.054-7219.173)$ & 0.323 \\
ICU & $0.310(0.022-4.401)$ & 0.387 \\
IMV & $18.040(1.178-276.210)$ & $\mathbf{0 . 0 3 8}$ \\
Length of hospital stay $(\geq 10$ day) & $3.250(0.345-30.250)$ & 0.3 \\
Confusion & $47.08(4.424-501.039)$ & $\mathbf{0 . 0 0 1}$ \\
Procalcitonin positivity & $13.412(1.950-92.234)$ & $\mathbf{0 . 0 0 8}$ \\
CURB65 $(\geq \mathbf{1})$ & $1.263(0.07-22.851)$ & 0.874 \\
Culture positivity & $4.298(0.467-39.542)$ & 0.198 \\
Neutrophil $(\geq 77)\left(10^{3} / \mu \mathrm{L}\right)$ & $1.011(0.145-7.03)$ & 0.991 \\
Urea $(\geq \mathbf{5 0})(\mathrm{mg} / \mathrm{dL})$ & $1.162(0.134-10.096)$ & 0.892 \\
\hline
\end{tabular}

$\mathrm{CI}$; confidence interval, OR; odds ratio, IMV; invasive mechanical ventilation, ICU; Intensive Care Unit

\section{Discussion}

Our results showed that invasive mechanical ventilation, confusion status and PCT positivity are independent risk factors for hospital mortality in CAP patients. In addition, increased levels of neutrophil ratio and CURB65 score and decreased systolic TA values were determined in patients with CAP requiring hospitalization.
Determination of factors associated with mortality may improve treatment strategies and management of hospitalized CAP patients. Nearly $20-25 \%$ of patients with CAP require in-patient treatment (11). Early mortality has been reported in some CAP studies between $2.3 \%-26.9 \%(4,12,13)$. Risk factors associated with short-term mortality in CAP patients were evaluated in a meta-analysis showed that 
seventeen factors (male sex, altered mental status, dyspnea, tachypnea, hypotension, hypothermia, congestive heart failure, alcohol abuse, diabetes mellitus, immunosuppression, neoplastic disease, coronary artery disease, neurologic disease, leukopenia, bacteremia, multi-lobar radiographic pulmonary infiltrate, and azotemia) were significantly related with higher risk of short-term mortality in these patients (14). In addition, increased age, altered mental status, multi-lobar pneumonia, shock at admission, pneumococcal bacteremia, discordant empiric antibiotic therapy, increased IL- 6 and TNF- $\alpha$ levels were found a risk factors for early (within the first 48 hours to 7 days after hospital admission) mortality in CAP $(12,15)$. Baek et al determined that chronic lung disease, mechanical ventilation, hemodialysis, and albumin were associated with in-hospital mortality of CAP in elderly patients (16). In addition, the area under the curve in pneumonia for predicting mortality was 0.61 for the CURB-65 score in this study. The severity scores of CAP have different strengths and weaknesses. CURB-65 had high specificity to determine of patients at high risk of requirement for ICU (17). In a systematic review and meta-analysis showed that severity scales to predicting mortality in CAP patients had good negative predictive values for mortality (18).

In multiple previous studies found that pretreatment levels of PCT have been associated with short-term mortality and mostly providing moderate to high prognostic value $(19,20)$. Increased admission levels of PCT was associated with adverse short-term outcome (intensive care unit admission and 30-day mortality) in addition to determines to bacterial etiology of CAP (21).

In one study which evaluated to prognostic factors of CAP in elderly patients, hospital mortality was $3.2 \%$ in $\leq 65$ years and $9.8 \%$ in $>65$ years old. This study results showed that advanced age ( $>83$ years old), presence of neurological disease, suspected aspiration, short clinical history ( $\leq 3$ days), absence of cough, arterial hypotension, tachypnea ( $>35$ breaths/min), metabolic acidosis (arterial $\mathrm{pH}$ $<7.35$ and actual bicarbonate level $\leq 18 \mathrm{mEq} / \mathrm{L}$ ), hypoxemia $\left(\mathrm{PaO}_{2}<52 \mathrm{mmHg}\right.$ with ambient $\left.\mathrm{FiO}_{2}\right)$, hypocapnia $\left(\mathrm{PaCO}_{2}<25 \mathrm{mmHg}\right)$, elevated serum urea nitrogen, hypernatremia, hyperpotassemia, hyperphosphoremia, hypoalbuminemia, multi-lobar radiographic involvement, risk class $\mathrm{V}$ (patients scoring $>130$ on Fine's index), use of two or three antibiotics at the time of admission, admission to the intensive care unit, and the need for mechanical ventilation are associated with a higher risk of in-hospital death in elderly CAP patients (22). In another study included 2.320 CAP patients found that advanced age, and a high comorbidity burden were common in patients who died in hospital. It has been shown in many previous studies that the presence of comorbidity is associated with especially longterm mortality in CAP patients (23-25). In a retrospective multicenter study performed in our country, CAP cases between 2011 and 2013 were evaluated. This study included 785 CAP patients and short-term mortality was found as $9.2 \%$. Higher PSI and BUN/albumin ratios, CURB-65, Charlson comorbidity scores and lower hematocrit levels were related with 30 day mortality (26). In our study results showed that invasive mechanical ventilation, confusion status and PCT positivity are independent risk factors for hospital mortality in CAP patients. Also, neutrophil ratio and CURB-65 score were increased and systolic TA were decreased in patients with CAP requiring hospitalization. Systolic hypotension was found in patients with non-survivor CAP patients compared with survivors but we did not determine the relationship between comorbidities and mortality in our study. Little is known about the causes and factors associated with mortality in the first 48 hours to 7 days of CAP. Moreover, the associated risk factors and the causes of mortality in patients with CAP can vary according to the time in which mortality is evaluated. 
Our study has some limitations. First, it was a retrospective study. The second limitation of our study is the fact that it is based on a single center with relatively small sample size. The third limitation of our study is evaluation of only culture positivity. Unfortunately, since it is a retrospective study, the factors that produced in culture could not be determined. In addition, causes of early mortality and antibiotherapy were not reported in patients with CAP.

In summary, CAP is a serious public health problem because it still has a high incidence and mortality rate despite the progress made in terms of mortality-related parameters in CAP patients. Our study are described some laboratory and epidemiological characteristics of patients with hospitalized CAP as regional data. We think that better understanding of predictors of hospital mortality may improve strategies for management of CAP.

In conclusion, short-term mortality in patients with hospitalized CAP is high level. Mechanical ventilation, confusion status and PCT positivity are independent risk factors for hospital mortality in CAP patients. In addition, increased levels of neutrophil ratio and CURB65 score and decreased systolic TA values have a significantly increased possibility of short-term mortality in these patients. In future studies, larger sample sizes and participation from several healthcare centers can provide results that can be generalized further.

\section{REFERENCES}

1. Musher DM, Thorner AR.: Community acquired pneumonia. N Engl J Med 2014; 371: 1619-28.

2. Kolditz M, Tesch F, Mocke L, et al.: Burden and risk factors of ambulatory or hospitalized CAP: a population based cohort study. Respir Med 2016; 121: 32-8.

3. Breitling LP, Saum KU, Schottker B, et al.: Pneumonia in the noninstitutionalized older population. Dtsch Arztebl Int 2016; 113: 60714.
4. Ewig S, Birkner N, Strauss R, et al.: New perspectives on community-acquired pneumonia in 388406 patients. Results from a nationwide mandatory performance measurement programme in healthcare quality. Thorax 2009; 64: 1062-9.

5. Corrales-Medina VF, Musher DM, Wells GA, et al.: Cardiac complications in patients with communityacquired pneumonia: incidence, timing, risk factors, and association with short-term mortality. Circulation 2012; 125: 773-81.

6. Dremsizov T, Clermont G, Kellum JA, et al.: Severe sepsis in community-acquired pneumonia: when does it happen, and do systemic inflammatory response syndrome criteria help predict course? Chest 2006; 129: 968-78.

7. Phua J, Ngerng WJ, Lim TK.: The impact of a delay in intensive care unit admission for community-acquired pneumonia. Eur Respir J 2010; 36: 826-33.

8. T.C. Sağlık Bakanlı̆̆ı, Refik Saydam Hıfzıssıhha Merkezi Başkanlığı Hıfzıssıhha Mektebi Müdürlüğü, Başkent Üniversitesi Ulusal Hastalık Yükü ve Maliyeti Etkinlik Projesi, 2004 (www.toraks.org.tr).

9. Türkiye İstatisitik Kurumu, Sağl1k İstatistikleri (http://www.tuik.gov.tr).

10. Özlü T, Bülbül Y, Özsu S.: Ulusal Verilerle Toplumda gelişen pnömoniler. Tüberküloz ve Toraks Dergisi 2007; 55: 191-212.

11. Viasus D, Cillóniz C, Cardozo CG, et al.: Early, short and long-term mortality in community-acquired pneumonia. Ann Res Hosp 2018; 2: 5.

12. Garcia-Vidal C, Fernández-Sabé N, Carratalà $\mathrm{J}$, et al.: Early mortality in patients with community-acquired pneumonia: causes and risk factors. Eur Respir J 2008; 32: 733-9.

13. Mortensen EM, Restrepo MI, Anzueto A, Pugh JA.: Antibiotic therapy and 48-hour mortality for patients with pneumonia. Am J Med 2006; 119: 859-64. 
14. Fine MJ, Smith MA, Carson CA, et al.: Prognosis and outcomes of patients with community-acquired pneumonia. A metaanalysis. JAMA 1996; 275: 134-41.

15. Bacci MR, Leme RC, Zing NP, et al.: IL-6 and TNF- $\alpha$ serum levels are associated with early death in community acquired pneumonia patients. Braz J Med Biol Res 2015; 48: 42732.

16. Baek MS, Park S, Choi JH, Kim CH, Hyun IG.: Mortality and Prognostic Prediction in Very Elderly Patients With Severe Pneumonia. J Intensive Care Med 2020; 35: 1405-10.

17. Williams JM, Greenslade JH, Chu KH, et al.: Utility of community-acquired pneumonia severity scores in guiding disposition from the emergency department: Intensive care or shortstay unit? Emerg Med Australas 2018; 30: 53846.

18. Loke YK, Kwok CS, Niruban A, Myint PK.: Value of severity scales in predicting mortality from community-acquired pneumonia: systematic review and meta-analysis. Thorax 2010; 65: 884-90.

19. Viasus D, Del Rio-Pertuz G, Simonetti AF, et al.: Biomarkers for predicting short-term mortality in community-acquired pneumonia: a systematic review and meta-analysis. J Infect 2016; 72: 273-82

20. Fernandez JF, Sibila O, Restrepo MI.: Predicting ICU admission in communityacquired pneumonia: clinical scores and biomarkers. Expert Rev Clin Pharmacol 2012;
5: 445-58.

21. Siljan WW, Holter JC, Michelsen AE, et al.: Inflammatory biomarkers are associated with aetiology and predict outcomes in community-acquired pneumonia: results of a 5-year follow-up cohort study. ERJ Open Res 2019; 5: 00014-2019.

22. Peñafiel Fs, O'Brien Solar A, et al.: Community-Acquired Pneumonia Requiring Hospitalization in Immunocompetent Elderly Patients: Clinical Features, Prognostic Factors and Treatment. Arch Bronconeumol 2003; 39: $333-40$.

23. Bruns AH, Oosterheert JJ, Cucciolillo $\mathrm{MC}$, et al.: Cause specific long-term mortality rates in patients recovered from communityacquired pneumonia as compared with the general Dutch population. Clin Microbiol Infect 2011; 17: 763-8.

24. Adamuz J, Viasus D, Jiménez-Martínez E, et al:: Incidence, timing and risk factors associated with 1-year mortality after hospitalization for community-acquired pneumonia. J Infect 2014; 68: 534-41.

25. Mortensen EM1, Kapoor WN, Chang CC, Fine MJ.: Assessment of mortality after longterm follow-up of patients with communityacquired pneumonia. Clin Infect Dis 2003; 37: 1617-24.

26. Akyil FT, Yalcinsoy M, Hazara A, et al.: Prognosis of hospitalized patients with community-acquired pneumonia. Pulmonol 2018; 24: 164-69. 